\title{
STUDI KASUS: ASUHAN KEPERAWATAN PADA PASIEN DENGAN ASFIKSIA NEONATORUM
}

\author{
Derma Wani Damanik ${ }^{1}$, Julwansa Saragih ${ }^{2}$, Riris Artha Dhita Purba ${ }^{3}$ \\ ${ }_{1,2,3}$ Akper Kesdam I/Bukit Barisan Pematangsiantar \\ Email: ${ }^{1}$ dermawanidamanik@gmail.com, ${ }^{2}$ saragihjuan02@gmail.com, ${ }^{3}$ ririspurba1207@gmail.com
}

\begin{abstract}
ABSTRAK
Asfiksia neonatorum merupakan suatu kondisi dimana bayi tidak mampu bernapas spontan dan teratur setelah lahir, dikarenakan oleh berkurangnya pasokan oksigen pada sel dan jaringan janin dalam uterus. Tujuan penelitian ini bertujuan untuk memahami rangkaian proses keperawatan pada pasien dengan asfiksia neonatorum. Metode penelitian ini menggunakan metode deskriptif dengan pendekatan melalui pengelolaan asuhan keperawatan pada Bayi R usia 0 hari. Metode studi kasus dilakukan di Rumah Sakit Tentara TK IV 010701 Pematangsiantar pada bulan April 2021. Pengumpulan data dilakukan dengan menggunakan format pengkajian bayi baru lahir melalui wawancara pada keluarga dan perawat serta observasi pada pasien. Berdasarkan pengkajian diperoleh data bayi sesak frekuensi 68x/menit, apgar score 5/6, irama nafas irregular, adanya retraksi dada, penggunaan otot bantu pernafasan, mata dan kulit kekuningan, urin kuning pekat, feces berwarna pucat, suhu tubuh $37,5^{\circ} \mathrm{C}$, peningkatan nilai bilirubin dan leukosit. Seluruh masalah teratasi, setelah dilakukan implementasi keperawatan selama 4 hari. Kesimpulan dari penelitian ini yaitu Implementasi yang dilakukan sesuai dengan rencana yang disusun sehingga masalah keperawatan pola nafas inefektif, ikterik neonatus dan resiko infeksi dapat teratasi.
\end{abstract}

Keywords: Asuhan Keperawatan, Pasien, Asfiksia Neonatorum.

\section{ABSTRACT}

Neonatal asphyxia is a condition in which the baby is unable to breathe spontaneously and regularly after birth, due to reduced oxygen supply to fetal cells and tissues in the uterus. The purpose of this study was to understand the series of nursing processes in patients with asphyxia neonatorum. This research method uses a descriptive method with an approach through the management of nursing care in Infant $R$ aged $O$ days. The case study method was carried out at Rumah Sakit Tentara TK IV 010701 Pematangsiantar in April 2021. Data collection was carried out using the newborn assessment format through interviews with families and nurses and observation of patients. Based on the study obtained data baby shortness of breath frequency 68x/minute, Apgar score 5/6, irregular breathing rhythm, chest retraction, use of accessory muscles for respiration, yellowish eyes and skin, dark yellow urine, pale stools, body temperature $37.5^{\circ} \mathrm{C}$, increased bilirubin and leukocyte values. All problems were resolved, after the implementation of nursing for 4 days. The conclusion of this study is that the implementation is carried out in accordance with the prepared plan so that the nursing problems of ineffective breathing patterns, neonatal jaundice and the risk of infection can be resolved.

Keywords: Nursing Care, Patient, Neonatorum Asphyxia.

\section{PENDAHULUAN}

Pelayanan kesehatan ibu dan anak adalah salah satu unsur penentu status kesehatan. Pelayanan kesehatan anak dimulai sebelum bayi lahir melalui pelayanan kesehatan yang diberikan kepada ibu hamil. Pertumbuhan dan perkembangan bayi pada masa neonatal adalah masa yang paling kritis karena bisa menyebabkan terjadinya kesakitan dan kematian bayi. Kematian pada masa perinatal paling banyak disebabkan oleh asfiksia (Utami, 2019).

Asfiksia neonatorum merupakan suatu kondisi dimana bayi tidak mampu bernapas spontan dan teratur setelah lahir, dikarenakan oleh berkurangnya pasokan oksigen pada sel dan jaringan janin dalam uterus, sehingga mengakibatkan tingginya angka kesakitan dan kematian pada bayi baru lahir (Putri, 2019). Asfiksia merupakan penyebab kematian tertinggi ketiga setelah infeksi neonatal dan prematuritas/bayi berat lahir rendah (Kemenkes, 2019) yang disebabkan oleh defisiensi surfaktan, pertumbuhan paru yang masih lemah, dan tulang iga yang mudah melengkung, sehingga janin tidak mendapatkan oksigen yang cukup dari plasenta (Yanti, 2017).

Data organisasi kesehatan dunia (WHO) menunjukkan bahwa penderita asfiksia 
neonatorum setiap tahunnya sebanyak 3,6 juta (3\%) dari keseluruhan jumlah bayi baru lahir yaitu 120 juta, dan sekitar 1 juta bayi diantaranya meninggal dunia (Sa'danoer, 2020). Berdasarkan hasil penelitian (Workineh et al, 2020) di Afrika Timur dan Tengah bahwa asfiksia neonatorum menyebabkan sekitar 4 juta kematian neonatal setiap tahun di dunia.

Berdasarkan hasil penelitian (Gebregziabher et al, 2020) di Rumah Sakit Spesialis Ethiopia Utara bahwa dari 267 neonatus, 48 orang diantaranya menderita asfiksia dengan prevalensi $18 \%$. Kematian neonatus yang disebabkan oleh asfiksia neonatorum sekitar 8 sampai $35 \%$ di negara maju, 31 sampai $56,5 \%$ di negara berkembang yang disebabkan oleh kondisi ibu, kondisi bayi, dan faktor plasenta (Notoatmodjo \& Rakhmawatie, 2012).

Angka kematian asfiksia neonatorum di Indonesia mencapai $29,9 \%$ yang berlangsung pada hari pertama bayi lahir, dan sebanyak 75,6\% terjadi setelah satu minggu kelahiran, sedangkan di Provinsi Lampung pada tahun 2017 terdapat 47 kejadian asfiksia neonatorum per 1000 neonatus (Rahmawati, 2019). Sementara itu, angka kejadian penderita asfiksia di Kota Pariaman tergolong tinggi, dimana tahun 2018 asfiksia menduduki urutan kedua yaitu sebanyak 267 kasus dan setiap bulannya yaitu sebanyak 22 bayi yang lahir dan menderita (Sa'danoer, 2020). (Farahdiba \& Rahmat, 2017) menambahkan bahwa kematian maternal bayi baru lahir pada tahun 2015 yang mengalami asfiksia mencapai $27 \%$.

Profil kesehatan Provinsi Sumatera Utara (2018) menunjukkan bahwa Angka Kematian Neonatal (AKN) sebesar 2,6 dari 1.000 kelahiran hidup dan Angka Kematian Bayi (AKB) sebesar 3,1 per 1.000 kelahiran hidup. Sedangkan penyebab kematian neonatal akibat asfiksia sebanyak 263 kasus.

Menurut (Tampubolon, 2019) asfiksia pada bayi baru lahir menjadi faktor yang menyebabkan kematian yaitu sebanyak 5 juta (19\%) dalam setiap tahun. Frekuensi asfiksia pada bayi dengan BBLR tertinggi terjadi pada tahun 2016 yaitu mencapai 18 bayi, pada tahun 2017 menurun menjadi 8 bayi, pada 2018 sebanyak 4 bayi dan tahun 2019 menurun Kembali menjadi 3 bayi.

Oleh sebab itu diperlukan peran perawat dalam membantu bayi baru lahir terutama bayi yang mengalami asfiksia, dapat diwujudkan dengan koordinasi yang baik, standar pelayanan yang berkualitas serta membekali perawat dengan pengetahuan serta sikap yang baik (Lumatauw et al., 2014). Studi kasus ini bertujuan untuk memahami rangkaian proses keperawatan pada pasien dengan asfiksia neonatorum.

\section{METODE STUDI KASUS}

Penelitian ini menggunakan pendekatan studi kasus pada pasien melalui proses keperawatan. Pasien dalam pelitian ini adalah By Ny R dengan jenis kelamin laki-laki, usia 0 hari. Pengambilan sampel menggunakan teknik purposive sampling. Penelitian dilakukan di Rumah Sakit Tentara TK IV 010701 Pematangsiantar pada bulan April 2021. Pengumpulan data dilakukan dengan menggunakan format pengkajian bayi baru lahir melalui wawancara pada keluarga dan perawat serta observasi pada pasien. Peneliti menggunakan 5 tahap proses keperawatan yang terdiri dari: 1). Pengkajian, peneliti mengumpulkan data yang berasal dari wawancara dengan keluarga pasien dan perawat, 2). Diagnosa keperawatan, melakukan analisisa data oleh peneliti untuk membantu dalam menegakkan diagnosa, 3). Intervensi keperawatan, dilakukan dengan menyusun perencanaan guna mengatasi masalah keperawatan yang ada, 4). Implementasi keperawatan, yaitu melakukan tindakan keperawatan sesuai dengan perencanaan yang telah dibuat, dan 5). Evaluasi Keperawatan, yaitu melaksanakan peneliti melakukan penilaian berdasarkan tahapan proses keperawatan yang sudah dilakukan.

\section{HASIL DAN PEMBAHASAN \\ 3.1 Hasil}

Hasil penelitian yang diperoleh berdasarkan tahapan proses keperawatan pada pengkajian adalah sebagai berikut: bayi lahir tidak segera menangis, jenis persalinan section cesarea dengan usia kehamilan 36 minggu, berat badan 2230 gr, panjang badan $46 \mathrm{~cm}$, dan nilai apgar score 5/6. keluhan utama bayi tampak sesak. Keadaan umum sedang, tanda-tanda vital: suhu $37,5^{\circ} \mathrm{C}$, nadi $144 x /$ menit, pernafasan $68 \mathrm{x} /$ menit. Pemeriksaaan fisik diperoleh ikterik pada lapisan conjuntiva, mukosa bibir kering, refleks mengisap lemah, nafas cepat, bunyi 
napas irreguler, adanya retraksi dada, terpasang oksigen $\left(\mathrm{O}_{2}\right) \quad 2$ liter/menit, terpasang mesin khusus yang berfungsi untuk menyalurkan oksigen atau yang disebut mesin CPAP, klien tampak rewel, kulit tampak kekuningan, rentang gerak lemah, urin kuning pekat, feces berwarna pucat.

Hasil pemeriksaan darah didapatkan nilai bilirubin indirek $12,08 \mathrm{mg} / \mathrm{dl}$, bilirubin direk $0,90 \mathrm{mg} / \mathrm{dl}$, dan nilai leukosit $16.000 / \mathrm{mm}^{3}$. Berdasarkan hasil analisa data, peneliti menetapkan 3 diagnosa keperawatan untuk kasus ini, merujuk kepada (Tim Pokja SDKI DPP PPNI, 2018) yaitu pola napas inefektif berhubungan dengan penekanan pusat pernapasan, gangguan upaya napas, sindrom hipoventilasi ditandai dengan bayi tampak sesak, frekuensi pernapasan 68x/menit, irama nafas irregular, adanya retraksi dada bagian dalam, menggunakan otot bantu pernafasan, oksigen terpasang 2 liter/menit, terpasang mesin khusus yang berfungsi untuk menyalurkan oksigen (CPAP). Diagnosa kedua yaitu ikterik neonatus berhubungan dengan kesulitan transisi kehidupan ekstra uterin, pola makan tidak tepat, usia $<7$ hari ditandai dengan warna kulit dan conjunctiva mata kekuningan, urin kuning pekat, feces berwarna pucat, nilai bilirubin indirek 12,08 $\mathrm{mg} / \mathrm{dl}$, bilirubin direk $0,90 \mathrm{mg} / \mathrm{dl}$. Diagnosa ketiga yaitu resiko tinggi infeksi berhubungan dengan peningkatan paparan organisme patogen lingkungan, ketidakseimbangan pertahanan tubuh primer ditandai dengan bayi rewel, suhu $37,5^{\circ} \mathrm{C}$, nilai leukosit 16.000 $\mathrm{mm}^{3}$.

Intervensi keperawatan pada kasus ini, peneliti menggunakan standart intervensi keperawatan Indonesia dari (Tim Pokja SDKI DPP PPNI, 2017). Untuk diagnosa pertama yaitu pola nafas inefektif, intervensi keperawatan terdiri dari: 1). Manajemen jalan nafas (observasi pola nafas, frekuensi, kedalaman, usaha nafas, bunyi nafas tambahan, pertahankan kepatenan jalan napas, beri posisi fowler atau semi fowler, berikan oksigen sesuai kebutuhan, 2). Pantau respirasi (monitor adanya sumbatan jalan nafas, lakukan perabaan kesimetrisan ekspansi paru, auskultasi bunyi nafas, monitor saturasi oksigen), 3). Dukungan ventilasi (identifikasi adanya penggunaan otot bantu pernafasan, kenali dampak berubahnya posisi dengan kondisi pernafasan, pantau penyerapan oksigen), 4). Pemberian obat (jelaskan jenis obat, alasan pemberian, tindakan yang diharapkan, dan efek samping sebelum pemberian, identifikasi kemungkinan alergi, interaksi, dan kontraindikasi obat, verifikasi order obat sesuai dengan indikasi, monitor pemberian obat), 5). Edukasi pengukuran respirasi (Identifikasi kesiapan dan kemampuan menerima informasi, siapkan bahan media pendidikan kesehatan, dokumentasikan hasil pengukuran).

Intervensi keperawatan untuk diagnosa kedua yaitu interik neonatus terdiri dari: 1). Fototerapi neonatus (monitor ikterik, indentifikasi kebutuhan jumlah cairan, minta ibu untuk menyusui bayi selama 20-30 menit), 2). Perawatan bayi (observasi tandatanda vital, mandikan bayi sebanyak 2 kali dalam sehari, rawat tali pusat), 3). Edukasi orang tua (indentifikasi pengetahuan dan kesiapan orangtua belajar tentang perawatan bayi, ajarkan keterampilan merawat bayi)

Intervensi keperawatan untuk diagnosa ketiga yaitu resiko tinggi infeksi yaitu: 1). Manajemen imunisasi atau vaksinasi (idendentifikasi riwayat kesehatan dan riwayat alergi, identifikasi kontraindikasi pemberian imunisasi, jadwalkan imunisasi pada waktu yang tepat), 2). Pencegahan infeksi (monitor adanya gejala infeksi lokal dan sistemik, batasi jumlah pengunjung, lakukan pencucian tangan sebelum dan sesudah kontak dengan pasien dan lingkungan pasien, pertahankan teknik aseptik pada resiko tinggi).

Implemetasi keperawatan dilakukan selama 4 hari, dimulai pada tanggal 14 April 2021 pukul 08.00 WIB. Untuk diagnosa pertama peneliti: 1). Melakukan manajemen jalan nafas 2). Melakukan pemantauan 3). Memberikan dukungan ventilasi, 4). Memberikan obat dexamethasone $0,7 \mathrm{mg} / 8$ jam, 5). Memberikan edukasi pengukuran respirasi. Implementasi pada diagnosa keperawatan kedua, peneliti melakukan fototerapi neonatus, melakukan perawatan bayi dan memberikan edukasi kepada orang tua tentang pengetahuan, kesiapan dan keterampilan perawatan bayi sedangkan implementasi untuk diangnosa ketiga peneliti melakukan manajemen imunisasi dan pencegahan infeksi dengan memantau adanya gejala infeksi lokal dan sistemik, batasi jumlah pengunjung, melakukan pencucian 
tangan sebelum dan sesudah kontak dengan pasien dan lingkungan pasien, memberikan injeksi cefotaxime $150 \mathrm{mg} / 8$ jam, memberikan injeksi gentamicin $20 \mathrm{mg} / 24 \mathrm{jam}$.

Hasil evaluasi keperawatan pada hari pertama pada tanggal 14 April 2021 untuk diagnosa pertama, data subjektif yaitu ibu klien mengatakan bayi masih sesak, data objektifnya klien masih tampak sesak, RR 68x/menit, irama nafas irregular, adanya penggunaan otot bantu pernafasan, adanya retraksi dada, terpasang oksigen 2 liter/menit, terpasang mesin khusus yang berfungsi untuk menyalurkan oksigen (CPAP), SPO2 88\%, sumbatan jalan nafas tidak ada, pulmo dalam batas normal, sistema tulang infak. Assessment masalah belum teratasi. Planning: lanjutkan intervensi.

Diagnosa kedua, data subjektifnya yaitu ibu mengatakan kulit bayi kuning. Data objektif yaitu mata dan kulit tampak berwarna kekuningan, urin kuning pekat, feces pucat, refleks mengisap lemah, terpasang infus dextrose 5\% 7 tts/menit, tampak ibu memberikan ASI, nilai bilirubin indirek 12,08 $\mathrm{mg} / \mathrm{dl}$, bilirubin direk 0,90 $\mathrm{mg} / \mathrm{dl}$. Assessment masalah belum teratasi. Planning: lanjutkan intervensi.

Diagnosa ketiga, data subjektif yaitu ibu klien mengatakan badan bayi hangat. Data objektif yaitu suhu tubuh $37,5^{\circ} \mathrm{C}$, badan teraba hangat, bayi tampak rewel, bayi belum dijadwalkan untuk imunisasi, nilai leukosit $16.000 \mathrm{~mm}^{3}$. Assasment masalah belum teratasi. Planning: lanjutkan intervensi.

Hasil evaluasi keperawatan pada hari kedua pada tanggal 15 April 2021 untuk diagnosa pertama, data subjektif yaitu ibu klien mengatakan sesak berkurang, data objektifnya klien tampak sesak namun sudah berkurang, RR 60x/menit, irama nafas irregular, adanya penggunaan otot bantu pernafasan, bunyi nafas tambahan tidak ada adanya retraksi dada, terpasang oksigen 2 liter/menit, terpasang mesin yang berfungsi untuk menyalurkan oksigen $(C P A P), \mathrm{SPO} 2$ $90 \%$, sumbatan jalan nafas tidak ada, pulmo dalam batas normal, sistema tulang infak. Assessment masalah belum teratasi. Planning: lanjutkan intervensi.

Diagnosa kedua, data subjektifnya, ibu mengatakan kulit bayi masih kuning. Data objektif yaitu mata dan kulit tampak berwarna kekuningan, urin kuning pekat namun berkurang, warna feces normal, tampak ibu memberikan ASI, refleks mengisap meningkat, terpasang infus dextrose $5 \% \quad 7 \quad$ tts/menit, nilai bilirubin indirek 12,08 $\mathrm{mg} / \mathrm{dl}$, bilirubin direk 0,90 $\mathrm{mg} / \mathrm{dl}$. Assessment masalah teratasi sebagian. Planning: lanjutkan intervensi. Diagnosa ketiga, data subjektif yaitu ibu klien mengatakan bayi sudah tidak demam. Data objektif yaitu suhu tubuh $36,8^{\circ} \mathrm{C}$, rewel berkurang, belum dilakukan pemeriksaan darah ulang, nilai leukosit $16.000 \mathrm{~mm}^{3}$. Assessment masalah teratasi sebagian. Planning: lanjutkan intervensi.

Hasil evaluasi keperawatan pada hari ketiga pada tanggal 16 April 2021 untuk diagnosa pertama, data subjektif yaitu ibu klien mengatakan bayi tidak sesak, data objektifnya RR 48x/menit, irama nafas reguler, tidak adanya penggunaan otot bantu pernafasan, bunyi nafas tambahan tidak ada retraksi dada tidak ada, terpasang oksigen 2 liter/menit jika sesak, SPO2 96\%, sumbatan jalan nafas tidak ada, pulmo dalam batas normal, sistema tulang infak. Mesin khusus yang berfungsi untuk menyalurkan oksigen (CPAP) tidak terpasang. Assasment masalah teratasi sebagian. Planning: lanjutkan intervensi. Diagnosa kedua, data subjektifnya yaitu ibu mengatakan warna kekuningan berkurang. Data objektif yaitu kulit bayi mulai tampak memerah, urin kuning jernih, warna feces normal, refleks mengisap kuat, masih terpasang infus dextrose $5 \% \quad 7$ tts/menit, nilai bilirubin indirek $5,68 \mathrm{mg} / \mathrm{dl}$, bilirubin direk $0,40 \mathrm{mg} / \mathrm{dl}$. Assessment masalah teratasi sebagian. Planning: lanjutkan intervensi. Diagnosa ketiga, data subjektif yaitu ibu klien mengatakan bayi sudah tidak demam. Data objektif yaitu suhu tubuh $36,5^{\circ} \mathrm{C}$, bayi tidak rewel, nilai leukosit menjadi $9200 \mathrm{~mm}^{3}$. Assessment masalah teratasi. Planning: intervensi dihentikan.

Hasil evaluasi keperawatan pada hari keempat pada tanggal 17 April 2021 untuk diagnosa pertama, data subjektif yaitu ibu klien mengatakan sesak tidak ada, data objektifnya RR 40x/menit, irama nafas teratur, otot bantu pernafasan tidak ada, bunyi nafas tambahan tidak ada retraksi dada tidak ada, SPO2 98\%, sumbatan jalan nafas tidak ada, pulmo dalam batas normal. Assessment masalah teratasi. Planning: intervensi dihentikan. Diagnosa kedua, data subjektifnya yaitu ibu mengatakan warna kulit sudah memerah. Data objektif yaitu 
kulit bayi tampak memerah, urin dan feces normal, refleks mengisap kuat, nilai bilirubin indirek $5,68 \mathrm{mg} / \mathrm{dl}$, bilirubin direk 0,40 $\mathrm{mg} / \mathrm{dl}$. Assessment: masalah teratasi. Planning: intervensi dihentikan.

\subsection{Pembahasan}

Pembahasan menjelaskan tentang proses keperawatan yang telah dilakukan oleh peneliti yang terdiri dari:

\section{- Pengkajian}

Tahap pengkajian merupakan tahap awal dalam melaksanakan pengumpulan data terkait masalah klien agar dapat memberi arah dalam intervensi keperawatan (Astar et al., 2018). Dalam hal ini peneliti mengkaji data identitas klien, riwaya kesehatan mencakup keluhan utama, riwayat penyakit sekarang, riwayat penyakit terdahulu, riwayat penyakit keluarga, riwayat antenatal, riwayat intranatal, keadaan bayi baru lahir, pemeriksaan umum, pemeriksaan atrometri pemeriksaan khusus (head to toe) dan pemeriksaan penunjang.

Berdasarkan hasil pengkajian diperoleh keluhan utama pada klien adalah sesak dengan nilai apgar score 5/6. Menurut (Fida \& Maya, 2014), asfiksia neonatorum memiliki gejala dan tanda yaitu dypsnea, pernapasan cuping hidung (kedua hidung kembang kempis), kebiruan dan nadi berdenyut cepat. Sementara itu gejala selanjutnya pada asfiksia neonatorum adalah pernafasan dalam, denyut jantung terus menurun, tekanan darah mulai menurun, anak terlihat lemas (flaccid), penurunan tekanan oksigen dalam darah $\left(\mathrm{PaO}_{2}\right)$, meningginya tekanan $\mathrm{CO}_{2}$ darah $\left(\mathrm{PaCO}_{2}\right)$, menurunnya $\mathrm{pH}$ (akibat asidosis respiratorik dan metabolik), yang digunakan sebagai sumber glikogen bagi tubuh anak dan metabolisme anaerob, serta perubahan sistem peredaran darah.

Data pemeriksaan fisik diperoleh bahwa mata dan kulit berwarna kekuningan, reflek mengisap kurang, pernafasan cepat, retraksi dada ada, rentang pergerakan lemah, urin berwarna kuning pekat, feces pucat, terpasang oksigen, terpasang mesin khusus yang berfungsi untuk menyalurkan oksigen. Sesuai dengan (Kemenkes, 2019) bahwa sekitar $26 \%$ bayi asfiksia akan mengalami gangguan pada pernafasan. Asfiksia terjadi karena kekurangan oksigen baik saat kehamilan, persalinan maupun saat lahir (Saptanto \& Anggraheny, 2014).

\section{- Diagnosa keperawatan}

Diagnosa keperawatan merupakan penilaian klinis perawat tentang respon klien terhadap kondisi atau kebutuhan kesehatan aktual atau potensial. Data yang diperoleh untuk diagnosa pola napas inefektif adalah bayi tampak sesak, frekuensi pernapasan 68x/menit, irama nafas irregular, adanya retraksi dada bagian dalam, penggunaan otot bantu pernafasan, oksigen terpasang 2 liter/menit, terpasang mesin khusus yang berfungsi untuk menyalurkan oksigen. Sesuai dengan (Tim Pokja SDKI DPP PPNI, 2017) bahwa gejala minor dan mayor untuk diagnosa pola nafas inefektif mencakup dipsnea, penggunaan otot bantu pernafasan, fase ekspirasi memanjang, pola nafas abnormal, pernafasan cuping hidung dan ventilasi semenit menurun. Penulis menetapkan diagnosa ikterik neonatus dengan memperoleh data yaitu warna kulit dan sklera mata kekuningan, urin kuning pekat, feces berwarna pucat, nilai bilirubin indirek 12,08 $\mathrm{mg} / \mathrm{dl}$, bilirubin direk 0,90 $\mathrm{mg} / \mathrm{dl}$. Ikterus untuk bayi baru lahir adalah meningkatnya kadar bilirubin pada jaringan terdalam ekstravaskuler menyebabkan kulit, selaput konjungtiva, dan bagian tubuh lainnya berwarna menguning. Ikterus patologik terjadi dalam 24 jam awal dengan bilirubin serum meninggi melebihi dari $5 \mathrm{mg} \%$ perhari (Puspita, 2018). Data yang diperoleh untuk diagnosa resiko tinggi infeksi yaitu bayi rewel, suhu $37,5^{\circ} \mathrm{C}$, nilai leukosit 16.000 $\mathrm{mm}^{3}$. Sesuai dengan (Tim Pokja SDKI DPP PPNI, 2017) bahwa batasan karateristik resiko infeksi yaitu demam, dan adanya tanda-tanda infeksi.

\section{- Intervensi keperawatan}

Dalam tahap intervensi dilakukan berdasarkan penyusunan prioritas masalah keperawatan. Intervensi merupakan serangkaian tindakan yang dapat mencapai tiap tujuan khusus (Astar et al., 2018). Intervensi adalah elemen kunci dari rencana asuhan keperawatan. Intervensi keperawatan yang direncanakan untuk diagnosa keperawatan pola nafas inefektif yaitu: manajemen jalan nafas, pemantauan respirasi, dukungan ventilasi, pemberian obat, dan edukasi pengukuran respirasi. Rasionalnya manajemen jalan nafas dan pemantauan respirasi dapat mengidentifikasi dan 
memastikan kepatenan jalan nafas dan dukungan ventilasi dapat memfasilitasi dalam mempertahankan pernafasan spontan untuk memaksimalkan pertukaran gas di paru-paru (Tim Pokja SIKI DPP PPNI, 2018). Didukung penelitian (Pratama n.d, 2018) bahwa intervensi keperawatan pada masalah pola nafas inefektif dapat dilakukan dengan memaksimalkan ventilasi, mendengarkan bunyi nafas, memantau status pernafasan dan oksigenasi, monitor kecepatan, irama, kedalaman, dan kesulitan bernafas, pantau pergerakan dada dan ketidaksimetrisan penggunaan otot bantu pernafasan, palpasi kesimetrisan ekspansi paru, dan pertahankan (kepatenan) jalan nafas.

Intervensi keperawatan untuk diagnosa interik neonatus terdiri dari: fototerapi neonatus, perawatan bayi dan edukasi orang tua. Rasionalnya pemberian fototerapi dapat menurunkan kadar bilirubin dan edukasi orang tua memberikan informasi dalam peningkatan pengasuhan fisik yang dibutuhkan bayi dalam tahun pertama kehidupan (Tim Pokja SIKI DPP PPNI, 2018). Sejalan dengan penelitian (Mulyati et al, 2019) bahwa fotoherapi merupakan terapi pilihan pertama yang dilakukan pada bayi dengan hyperbilirubinemia. Intervensi keperawatan untuk diagnosa resiko tinggi infeksi yaitu: manajemen imunisasi atau vaksinasi dan pencegahan infeksi. Rasionalnya manajemen imunisasi/vaksinasi dapat mengidentifikasi dan mengelola pemberian kekebalan tubuh secara aktif dan pasif dan resiko infeksi dapat menurunkan resiko terserang organisme patogenik (Tim Pokja SIKI DPP PPNI, 2018). Penelitian (Yulia Sari, 2020) bahwa intervensi keperawatan untuk diagnosa resiko tinggi infeksi yaitu pantau gejala infeksi lokal dan sistemik, batasi jumlah pengunjung, cegah masuknya mikroorganisme ke dalam tubuh bagi pasien dengan resiko tinggi.

- Implementasi keperawatan

Berdasarkan kasus diketahui bahwa implementasi yang dilakukan sudah sesuai dengan perencanaan/intervensi yang disusun oleh peneliti. Penulis berusaha semaksimal mungkin untuk melakukan tindakan keperawatan sehingga tercapainya tujuan yang diharapkan. Outcome yang diperoleh pada diagnosa pola napas inefektif yaitu frekuensi dan irama nafas membaik, ventilasi semenit membaik, sesak menurun, dan penggunaan otot bantu nafas menurun. Outcome untuk diagnosa ikterik neonatus yaitu integritas kulit dan jaringan membaik, eliminasi fekal dan status nutrisi membaik. Dan outcome diagnosa yaitu resiko infeksi terkontrol. Menurut (Astar et al., 2018), sebelum melakukan implementasi yang sudah direncanakan perawat perlu melakukan validasi secara singkat untuk mengetahui apakah rencana tindakan masih sesuai dan dibutuhkan klien sesuai dengan kondisi pada saat ini. Perawat juga perlu memberikan penilaian terhadap diri sendiri, apakah memiliki kemampuan interpersonal, intelektual, dan teknik sesuai dengan tindakan yang akan dilakukan. (Shiferaw et al, 2020) menambahkan implementasi keperawatan dalam pengaturan klinis dapat memfasilitasi asuhan keperawatan yang berkualitas tinggi dan meningkatkan hasil kesehatan klien.

- Evaluasi

Pada penelitian ini, ketiga masalah sudah teratasi setelah tindakan keperawatan dilakukan selama 4 hari. Sesuai dengan pendapat (Nursalam, 2014) bahwa evaluasi dilakukan berdasarkan kriteria yang telah ditetapkan dalam perencanaan dan membandingkan hasil tindakan yang telah dilaksanakan secara berkesinambungan serta menilai efektifitas proses keperawatan mulai dari tahap pengkajian, perencanaan dan pelaksanaan.

\section{KESIMPULAN}

By Ny R dengan jenis kelamin laki-laki, usia 0 hari dengan keluhan utama sesak. Diperoleh 3 masalah utama yaitu pola nafas inefektif, ikterus neonatus, dan resiko tinggi infeksi. Sesudah tindakan keperawatan dilakukan selama 4 hari, maka ketiga ketiga masalah keperawatan yaitu pola nafas inefektif, ikterik neonatus dan resiko infeksi, teratasi. Dengan pengetahuan perawat yang baik sangat bermanfaat untuk meningkatkan implementasi proses keperawatan. Oleh sebab itu, perawat dapat dididik tentang pentingnya pengetahuan guna meningkatkan implementasi proses keperawatan dan kualitas asuhan keperawatan secara keseluruhan. 


\section{REFERENCES}

Astar, F., Tamsah, H., \& Kadir, I. (2018). Pengaruh Pelayanan Asuhan Keperawatan terhadap Kepuasan Pasien di Puskesmas Takalala Kabupaten Soppeng. YUME: Journal of Management, 1 (2).

Farahdiba, I., \& Rahmat, B. (2017). Faktorfaktor yang berhubungan terjadinya asfiksia pada bayi baru lahir di Rumah Sakit Syech Yusuf Gowa Tahun 2017. Jurnal Kesehata Delima Pelamonia, 1 (2), 185-192.

Fida., \& Maya. (2014). Pengantar Ilmu Kesehatan Anak. D-Medika: Yogyakarta.

Gebregziabher, G. T., Hadgu, F. B., \& Abebe, H. T. (2020). Prevalence and associated factors of perinatal asphyxia in neonates admitted to ayder comprehensive specialized hospital, Northern Ethiopia: a cross-sectional study. International Journal of Pediatrics.

Kemenkes. (2019). Keputusan Menteri Kesehatan Republik Indonesia No 214. Diakses pada https://yankes.kemkes.go.id.

Lumatauw, S., Kumaat, L. T., \& Karundeng, M. (2014). Hubungan pengetahuan dan sikap perawat dengan penanganan asfiksia berat pada bayi baru lahir Di Ruang Nicu Rsup Prof Dr RD Kandou Manado. Jurnal Keperawatan. 2 (2).

Mulyati, M., Iswati, N., \& Wirastri, U. (2019). Analisis Asuhan Keperawatan pada Pasien Neonatus dengan Hiperbilirubinemia di RSUD Prof. dr. Margono Soekarjo Purwokerto. Proceeding of The URECOL, 203-212.

Notoatmodjo, H., \& Rakhmawatie, M. D. (2012). Faktor-Faktor Yang Berhubungan Dengan Kejadian Asfiksia Neonatorum. Jurnal Kedokteran Muhammadiyah, 1 (2).

Nursalam, D. (2014). Manajemen Keperawatan: Aplikasi dalam Praktik Keperawatan Profesional. Salemba Medika.

PPNI, Tim Pokja SDKI D P P. (2017). Standar diagnosis keperawatan indonesia.

PPNI, Tim Pokja SIKI D P P. (2018). Standar intervensi keperawatan indonesia.
Pratama, R. T. B. (n.d.). (2018). Asuhan keperawatan pada By. $M$ dan By. L pasca asfiksia neonatorum dengan masalah keperawatan Ketidakefektifan pola nafas di Ruang perinatologi RSUD Dr. Haryoto Lumajang Tahun 2018.

Profil Kesehatan. (2018). Provinsi Sumatera Utara 2018. Dibuka pada website http: kemenkes.go.id. Dibuka pada 1 Maret 2021.

Puspita, N. (2018). The Effect of Low Birthweight on the Incidence of Neonatal Jaundice in Sidoarjo. Jurnal Berkala Epidemiologi, 6(2), 174. https://doi.org/10.20473/jbe.v6i22018.17 4-181.

Putri, N. N. B. K. A. (2019). Analisis faktor penyebab kejadian asfiksia pada bayi baru lahir di RS Aura Syifa Kabupaten Kediri. Jurnal Ners Dan Kebidanan (Journal of Ners and Midwifery), 6(2), 251-262.

Rahmawati, R. (2019). Faktor-faktor risiko yang berhubungan dengan kejadian asfiksia neonatorum (Studi di RSUD $d r$. Soekardjo Kota Tasikmalaya Tahun 2019). Universitas Siliwangi.

Sa'danoer, I. M. (2020). Faktor yang Berhubungan dengan Kejadian Asfiksia Neonatorum di RSUD Pariaman. Jurnal Bidan Komunitas, 3(3), 93-98.

Saptanto, A., \& Anggraheny, H. D. (2014). Faktor Risiko yang Mempengaruhi Kematian Bayi Asfiksi. Jurnal Kedokteran Muhammadiyah, 3(1).

Shiferaw, W. S., Akalu, T. Y., Wubetu, A. D., \& Aynalem, Y. A. (2020). Implementation of Nursing Process and Its Association with Working Environment and Knowledge in Ethiopia: A Systematic Review and Meta-Analysis. Nursing Research and Practice, 2020.

Tampubolon, I. K. (2019). Angka kejadian asfiksia pada bayi Berat Badan Lahir Rendah (BBLR) di Rumah Sakit Umum Pusat Haji Adam Malik.

Utami, R. P. (2019). Faktor-faktor yang berhubungan dengan kejadian asfiksia neonatorum di Rumah Sakit Umum daerah H. Abdul Manan Simatupang Kabupaten Asahan tahun 2017.

Yanti, J. S. (2017). Hubungan hipertensi kehamilan dengan asfiksia neonatorum di RSUD Arifin Achmad. Menara Ilmu, 
11(76).

Yulia Sari, D. (2020). Asuhan Keperawatan

pasien dengan gangguan kebutuhan

oksigenasi pada kasus pneumoni terhadap By $R$ DI Ruang Neonatus RSUD Mayjend HM Ryacudu Kotabumi Lampung Utara. Poltekkes Tanjungkarang.

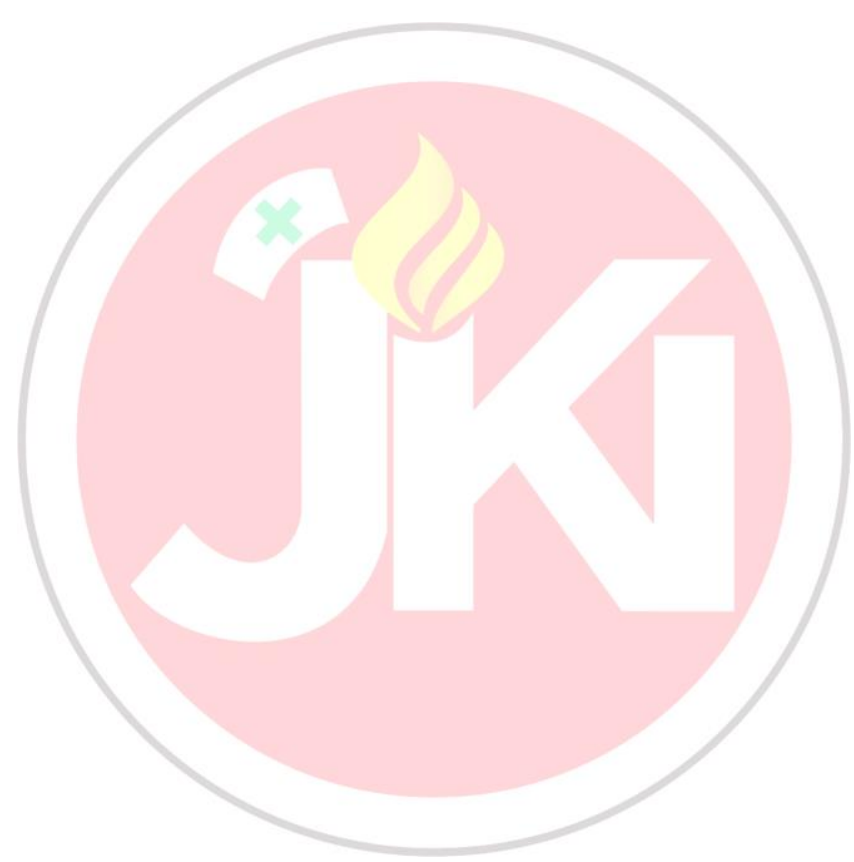

